\title{
EKSISTENSI ILMU PENGETAHUAN DI ERA REVOLUSI 4.0
}

\author{
${ }^{1}$ Rohma Kubro, ${ }^{2}$ Ahmad Satrio, ${ }^{3}$ Mulhatur Rofi'ah, ${ }^{4}$ Akhmad \\ Faidlaani, ${ }^{5}$ Muhammad Reza
}

Prodi Pendidikan Agama Islam, Fakultas Ilmu Sosial

Universitas Negeri Jakarta, Indonesia

Email: rohmakubro@gmail.com

\begin{abstract}
Abstrak
This study is literature study with descriptive qualitative research with library research. This research is intended to explain the existence of science in the industrial revolution era 4.0. In this literature study, the author uses various written sources such as book, journal, and documents that are relevant to the study in this study. This study focuses on science and its existence in the industrial revolution era. The study results show that the existence of science at this time is still very much needed and has increased significantly. This is because the development of technology based on science has spread and entered the joints of aspects of human life..
\end{abstract}

Keywords : Industrial Revolution 4.0, Science, Technology.

\section{A. PENDAHULUAN}

Manusia sebagai makhluk dengan penciptaan paling sempurna diberikan kelebihan yang membedakannya dari binatang, yaitu akal. Akal menjadi sarana berfikir seorang manusia dalam setiap kegiatan di kehidupnya. Kemampuan berfikir yang dimiliki oleh manusia ini juga menjadi salah satu sarana untuk bertahan hidup. Membedakan yang salah dan benar sudah menjadi kegiatan yang hampir setiap saat dilakukan oleh seorang manusia. Dalam melakukan kegiatan tersebut, manusia menggunakan akalnya untuk mendapatkan berbagai ilmu pengetahuan.

Melalui ilmu pengetahuan, manusia berkembang dan memperoleh berbagai kemudahan dalam menjalankan kehidupannya. Dalam Islam, pentingnya keberadaan ilmu pengetahuan membuat manusia yang 
memilikinya diangkat derajatnya. Hal ini dijelaskan di dalam Al-Quran surat Al-Mujadalah ayat 11 yang mengandung arti “... Niscaya Allah akan mengangkat (derajat) orang-orang yang beriman diantara kamu dan orangorang yang diberi ilmu beberapa derajat. Dan Allah Maha Mengetahui terhadap apa yang kamu kerjakan". Hal ini dipertegas melalui Hadist dari Abu Hurairah r.a , Rasulullah Saw bersabda "Barang siapa menelusuri jalan untuk mencari ilmu padanya, Allah akan memudahkan baginya jalan menuju surga" (HR Muslim).

Memasuki era revolusi industri 4.0, manusia dituntut memiliki softskill yang terbarukan guna menghadapi berbagai perubahan yang terjadi dalam era ini. Perkembangan teknologi yang sangat pesat menjadi ikon utama pada era ini. Pada era revolusi industri 4.0, berbagai kemajuan teknologi seolah sudah menjadi teman setia atas perkembangan peradaban manusia. Istilah Industri 4.0 sendiri secara resmi lahir di Jerman tepatnya saat diadakan Hannover Fair pada tahun 2011 (Hoedi dan Wahyudi, 2017: 18). Dalam cepatnya laju perkembangan teknologi, ilmu pengetahuan juga mengalami banyak pembaharuan yang tidak kalah cepat. Artikel ini akan menjawab rumusan masalah bagaimana eksistensi ilmu pengetahuan di era revolusi industri 4.0.

\section{B. METODE PENELITIAN}

Penelitian ini merupakan penelitian kualitatif dengan Teknik analisis deskriptif dengan kajian kepustakaan (library research) dimana penelitian ini berusaha untuk menjelaskan mengenai eksistensi atau keberadaan ilmu pengetahuan di era revolusi industri 4.0. artikel ini menyoroti banyak hasil jurnal, buku, maupun dokumen tertulis lainnya yang mengandung hal yang relevan untuk penelitian ini. 


\section{HASIL DAN PEMBAHASAN}

\section{(1) Ilmu Pengetahuan}

Penalaran berarti berpikir dengan menggunakan nalar atau rasio (Jalaluddin, 2013: 109). Sabarti (dalam Jalaluddin, 2013) juga menjelaskan penalaran dapat diartikan sebagai operasi intelek ketiga yang tidak hanya berhenti pada konsep, proposisi, dan penilaian, melainkan juga menghasilkan pengetahuan baru berdasarkan atas pengetahuan yang telah dicapai. Dalam menghasilkan pengetahuan baru, proses penalaran ini haruslah mempertimbangkan hal-hal yang logis. Logis berarti penalaran itu dilakukan dengan pola penalara tertentu Hayu Wibowo (dalam jalaluddin, 2013) .

Melihat dari sejarah yang telah tertulis, peradaban manusia dengan perkembangan ilmu pengetahuan menjadikannya dua sisi yang sangat melekat. Pengetahuan dalam Kamus Besar Bahasa Indonesia memiliki pengertian segala sesuatu yang diketahui. Pengetahuan diperoleh dari hasrat ingin tahu. Semakin kuat hasrat ingin tahu manusia, akan semakin banyak pengetahuannya (Martini Djamaris, 2011: 102). Hasrat keingin tahuan yang dimiliki seorang manusia memotivasi dirinya untuk terus mencari sesuatu yang baru di luar dirinya (Jalaluddin, 2013: 14). Proses ini dilihat sebagai peranan ciri kreativitas manusia dalam menimbulkan ide-ide inovatif yang menuju kepada pengetahuan baru ataupun penemuan baru, baik dengan menempuh cara yang sudah mengandung dimensi ilmiah maupun yang masih belum (Conny R. Semiawan, 1988:3).

Daoed Joesoef (dalam Surajiyo, 2014: 2) menunjukkan bahwa pengertian ilmu mengacu pada tiga hal, yaitu : produk, proses, masyarakat. Ilmu pengetahuan sebagai produk yaitu pengetahuan yang telah diketahui dan diakui kebenarannya oleh masyarakat ilmuwan. Pengetahuan ilmiah dalam hal ini terbatas pada kenyataan-kenyataan yang mengandung kemungkinan untuk disepakati dan terbuka untuk diteliti, diuji dan dibantah oleh seseorang. Sedangkan dalam perspektif 
Islam, ilmu merupakan pengetahuan mendalam hasil usaha yang sungguh-sungguh (ijtihād) dari para ilmuwan muslim ('ulamā'/mujtahīd) atas persoalanpersoalan duniawī dan ukhrāwī dengan bersumber kepada wahyu Allah (Kosim, 2008: 122).

Pengetahuan dapat disebut sebagai ilmu pengetahuan, apabila dalam proses memperolehnya digunakan pendekatan ilmiah. Pendekatan yang merupakan gabungan antara penalaran induktif dan deduktif. Rangkaian dari proses berpikir yang bergerak secara induktif dari pengamatan menuju hipotesis, dan kemudian berbalik secara deduktif membuat verifikasi atas hipotesis tadi kepada penerapan logisnya. Dengan adanya pendekatan ini, maka ilmu pengetahuan jadi terbedakan dari pengetahuan yang bersumber dari pengalaman (Aceng Rahmat: 15).

Ilmu pengetahuan pada dasarnya adalah kelanjutan konseptual dan ciri- ciri "ingin tahu" sebagai kodrat manusiawi (Anton Backer dan Achmad Charris Zubair:14). Ilmu pengetahuan bertujuan untuk mengonseptualisasikan fenomena-fenomena alam dalam sebab-sebab, dalam urutan-urutan sebab akibat, dalam mencari asas-asas umum (Bakker, 1984: 38). Ilmu pengetahuan dalam Islam bisa dicapai melalui tiga sumber/alat; indra, akal budi, dan hati, sedangkan dalam epistemologi Barat, pengetahuan ilmiah hanya bisa diraih melalui indra dan akal (Kosim, 2008: 127).

\section{(2) Sejarah Perkembangan Ilmu Pengetahuan}

Secara teoritis perkembangan ilmu pengetahuan selalu mengacu kepada peradaban Yunani. Hal ini didukung oleh beberapa faktor, di antaranya adalah mitologi bangsa Yunani, kesusastraan Yunani, dan pengaruh ilmu pengetahuan pada waktu itu yang sudah sampai di Timur Kuno. Dalam setiap periode sejarah pekembangan, ilmu pengetahuan memiliki ciri khas atau karakteristik tertentu. Tetapi dalam pembagian periodisasi perkembangan ilmu pengetahuan ada perbedaan dalam berbagai literature yang ada. Amsal Bakhtiar 
membagi periodeisasi sejarah perkembangan ilmu pengetahuan menjadi empat periode: pada zaman Yunani kuno, pada zaman Islam, pada zaman renaisans dan modern, dan pada zaman kontemporer (Abdul Karim, 2014: 274-275).

Sedangkan George J. Mouly membagi perkembangan ilmu menjadi tiga (3) tahap yaitu animisme, ilmu empiris dan ilmu teoritis.Goerge J. Mouly menjelaskan pada tahap animisme, ilmu pengetahuan masih sering kali dihubungkan dengan unsur-unsur mitos. Selanjutnya, ia menjelaskan bahwa lambat laun manusia menyadari bahwa gejala alam dapat diterangkan sebab- musababnya. Pada saat itulah perkembangan ilmu memasuki tahap ilmu empiris. Tingkat yang paling akhir dari ilmu menurut Goerge adalah ilmu teoritis, di mana hubungan dan gejala yang ditemukan dalam ilmu empiris diterangkan dengan dasar suatu kerangka pemikiran tentang sebab-musabab sebagai langkah untuk mengontrol kegiatan agar hasil yang diharapkan dapat dicapai (Jalaluddin, 2013: 17-21).

\section{(3) Jenis-jenis Ilmu Pengetahuan}

Di dalam kehidupan manusia dapat memiliki berbagai pengetahuan dan kebenaran. Burhanuddin Salam (Dalam Rusmini, 2014: 82) mengemukakan bahwa pengetahuan yang dimiliki manusia ada empat, yaitu pengetahuan biasa, pengetahuan ilmu, pengetahuan filsafat, dan pengetahuan agama.

a. Pengetahuan biasa

Pengetahuan biasa yaitu pengetahuan yang dalam filsafat dikatakan dengan istilah common sense dan sering diartikan dengan good sense, karena seseorang memiliki sesuatu di mana ia menerima secara baik. Common sense diperoleh dari pengalaman sehari-hari, seperti air dapat dipakai untuk menyiram bunga, makanan dapat memuaskan rasa lapar, dan sebagainya.

b. Pengetahuan ilmu 
Pengetahuan ilmu yaitu ilmu sebagai terjemahan dari science. Ilmu pada prinsipnya merupakan usaha untuk mengorganisasikan dan mensistematisasikan common sense, suatu pengetahuan yang berasal dari pengalaman dan pengamatan dalam kehidupan sehari-hari, kemudian dilanjutkan dengan suatu pemikiran secara cermat dan teliti dengan menggunakan berbagai metode.

c. Pengetahuan filsafat

Pengetahuan filsafat yaitu pengetahuan yang diperoleh dari pemikiran yang bersifat kontemplatif dan spekulatif. Pengetahuan filsafat lebih menekankan pada universalitas dan kedalaman kajian tentang sesuatu, dan biasanya memberikan pengetahuan yang lebih menekankan pada universalitas dan kedalaman kajian tentang sesuatu, dan biasanya memberikan pengetahuan yang reflektif dan kritis.

d. Pengetahuan agama

Pengetahuan agama yaitu pengetahuan yang hanya diperoleh dari Tuhan melalui para utusan-Nya, yang bersifat mutlak dan wajib diyakini oleh para pemeluk agama.Pengetahuan agama yaitu pengetahuan yang hanya diperoleh dari Tuhan melalui para utusan-Nya, yang bersifat mutlak dan wajib diyakini oleh para pemeluk agama.

Lebih lanjut, pengetahuan ini terus berkembang dan membentuk berbagai macam jenis ilmu pengetahuan yang ada di kehidupan seorang manusia. Penggolongan ilmu sebagaimana dikutip dari Surajiyo (dalam Rusmini, 2014: 91-92) sebagai berikut:

a. Ilmu Formal dan Ilmu Nonformal

Suatu ilmu disebut Ilmu Formal karena ilmu ini dalam seluruh kegiatannya tidak bermaksud menyelidiki data-data inderawi yang konkret. Misalnya matematika dan filsafat. Suatu ilmu disebut Ilmu Nonformal karena di dalam ilmu ini 
pengalaman inderawi memainkan peranan sentral/utama. Ilmu ini dalam seluruh kegiatannya berusaha menyelidiki secara sistematis data-data inderawi yang konkret. Misalnya ilmu hayat, ilmu alam, dan ilmu manusia.

b. Ilmu Murni dan Ilmu Terapan

Ilmu Murni adalah ilmu yang bertujuan meraih kebenaran demi kebenaran (teoretis). Misalnya matematika dan metafisika. Ilmu Terapan adalah ilmu yang bertujuan untuk diaplikasikan atau diambil manfaatnya (praktis). Misalnya ilmu kedokteran, teknik, hukum, ekonomi, psikologi, sosiologi, administrasi, dan ekologi.

c. Ilmu Nomotetis dan Ilmu Idiografis

Ilmu Nomotetis adalah ilmu yang objek pembahasannya merupakan gejala pengalaman yang dapat diulangi terusmenerus dan hanya merupakan kasus-kasus yang mempunyai hubungan dengan suatu hukum alam. Termasuk dalam ilmu ini adalah ilmuilmu alam, yang objek pembahasannya adalah benda alam atau gejala alam, yang didekati dengan cara menerangkan. Ilmu Idiografis adalah ilmu yang objek pembahasannya merupakan objek yang bersifat individual, unik, yang hanya terjadi satu kali dan mencoba mengerti atau memahami objeknya menurut keunikannya itu. Termasuk dalam ilmu ini adalah ilmuilmu budaya, yang objek pembahasannya adalah produk manusiawi, yang didekati dengan cara mengerti atau memahami.

d. Ilmu Deduktif dan Ilmu Induktif

Suatu ilmu disebut Ilmu Deduktif karena semua pemecahan yang dihadapi dalam ilmu ini tidak didasarkan atas pengalaman inderawi (empiris), melainkan atas dasar deduksi atau penjabaran. Deduksi ialah proses pemikiran yang melibatkan akal budi manusia dari pengetahuan tentang hal-hal 
yang umum dan abstrak, menyimpulkan tentang hal-hal yang bersifat khusus dan individual. Misalnya matematika. Suatu ilmu disebut Ilmu Induktif apabila penyelesaian masalahmasalah dalam ilmu yang bersangkutan didasarkan atas pengalaman inderawi (empiris). Ilmu Induktif bekerja selalu atas dasar induksi, yaitu proses pemikiran yang melibatkan akal budi manusia dari pengetahuan tentang hal-hal yang bersifat khusus dan individual, menarik kesimpulan tentang hal-hal yang bersifat umum dan abstrak, Misalnya ilmu alam.

\section{(4) Revolusi Industri 4.0}

Dewasa ini, kalimat revolusi industri 4.0 seakan sudah banyak berkenalan dengan telinga di seluruh kalangan masyarakat. Kalimat tersebut seringkali dijadikan sebagai sebuah topik pembicaraan dalam berbagai pertemuan, dijadikan sebuah judul dalam berbagai penelitian, atau sekedar dijadikan kalimat pemanis yang membakar jiwa semangat kontribusi dalam motivasi kepada kaum muda. Revolusi Industri 4.0 merupakan sebutan untuk sebuah revolusi yang sudah terjadi di masa ke-empat setelah awal kedatangannya di abad ke-18 yang ditandai dengan ditemukannya mesin uap.

Ciri khas yang ada pada era revolusi industri 4.0 adalah perkembangan pesat dibidang teknologi. Setelah "globalisasi" yang sebelumnya menjadi primadona sebagai ikon kemajuan masa kini, revolusi industri 4.0 hadir dengan peran lanjutannya yang lebih meluas hampir di seluruh aspek kehidupan manusia. Dilansir dari accurate, pilar utama era revolusi industri 4.0 adalah teknologi berbasis digital. Pengembangan teknologi ini memerlukan pengetahuan yang luas, kompeten, dan didukung juga oleh kemampuan yang matang.

\section{(5) Eksistensi Ilmu Pengetahuan}

Eksistensi dalam Kamus Besar Bahasa Indonesia memiliki arti keberadaan. Lebih lanjut, eksistensi ilmu pengetahuan dapat diartikan 
sebagai keberadaan ilmu pengetahuan yang dinilai dalam suatu masa. Eksistensi ilmu pengetahuan di era revolusi industri 4.0 adalah penilaian terhadap keberadaan ilmu pengetahuan di masa revolusi industri 4.0.

Teknologi yang berkembang dengan pesat tidak lepas dari peranan ilmu pengetahuan yang juga turut berkembang menuju berbagai pembaharuan. Ilmu pengetahuan sebagai salah satu aspek dasar kehidupan manusia menjadikan kehadirannya berperan aktif dalam aspek-aspek pendukung lainnya yang ada di kehidupan seorang manusia. Berbagai penemuan teknologi terbaru di era revolusi indistri 4.0 ini menunjukan bahwa eksistensi ilmu pengetahuan yang menjalar bebas dan cenderung meningkat secara signifikan. Pada era ini, orangorang saling berlomba untuk menempuh setinggi mungkin Pendidikan baik secara formal maupun non-formal. Hal ini dilakukan untuk terus memperbaharui kemampuan diri dan ilmu pengetahuan.

Ilmu pengetahuan pada era revolusi industri 4.0 ini seolah menjadi kembang desa yang tak pernah pudar kecantikannya. Ilmu pengetahuan meluas dan terus merasuki segala sendi-sendi kehidupan manusia. Ilmu pengetahuan seolah tetap menjadi induk dari segala kemajuan teknologi yang saat ini berkembang. Berbagai bidang kehidupan juga sudah turut mewarnai dan diwarnai oleh perkembangan ilmu pengetahuan di era revolusi industri 4.0 saat ini. Pendidikan sebagai wadah utama dalam penyampaian ilmu pengetahuan pun turut serta berkontribusi dalam eksistensi ilmu pengetahuan di masa ini.

Freud Pervical dan Henry Ellington (dalam Syamsuar dan Reflianto, 2018) menyatakan inovasi pembelajaran yang dilakukan di berkembangnya teknologi informatsi digital adalah memanfaatkan sarana teknologi informasi yang berkembang pesat di era revolusi industri 4.0 ini untuk meningkatkan mutu pembelajaran. Budiman (dalam Yus Dkk, 2019: 4) juga menjelaskan bahwa keberadaan 
teknologi yang semakin canggih pula memudahkan berlangsungnya proses pembelajaran. Keberadaan teknologi menjadikan pendidikan bergeser dari model konvensional yang mengharuskan guru melakukan tatap muka dengan siswa menjadi pembelajaran yang lebih fleksibel. Dalam kondisi seperti ini, guru maupun siswa secara tidak langsung dituntut untuk memiliki ilmu pengetahuan, minimal ilmu pengetahuan mengenai cara mengoperasionalkan telefon genggam dan internet yang ada di dalamnya.

Selain merambah pada Pendidikan, eksistensi ilmu pengetahuan pada era revolusi industri 4.0 juga memasui dunia perekonomian. Penggunaan teknologi yang canggih mulai banyak dijadikan fokus utama untuk mengembangkan ekonomi. Hal ini dapat kita lihat melalui perubahan sistem transportasi yang berkembang di masyarakat, salah satunya pada transportasi kereta api. Jika dimasa lalu pembelian karcis berbentuk selembar kertas kerap digunakan, maka di era teknologi ini karcis tersebut berubah menjadi kartu dan uang yang sepaket berada di dalamnya. Dalam mengembangkan metode pembayaran yang lebih modern ini, kehadiran ilmu pengetahuan sudah mutlak digunakan didalamnya. Ada banyak disiplin ilmu pengetahuan yang digunakan dalam proses pengembangan teknologi tersebut, seperti ilmu pengetahuan matematika, ilmu pengetahuan mengenai komputer dan jaringan, dan juga ilmu pengetahuan mengenai aliran listrik.

Tidak berhenti pada dunia Pendidikan dan ekonomi, eksistensi ilmu pengetahuan di era revolusi industri 4.0 juga ikut serta mewarnai dunia kesehatan. Kesehatan sebagai faktor yang sangat penting dalam kehidupan manusia, menjadikannya terus memperbaharui berbagai elemen-elemen yang dikandungnya. Hal ini dilakukan guna meningkatkan kualitas pengobatan manusia dan menekan angka kematian akibat penyakit yang diderita. Lagut Sutandra dan Sulaiman (2019) dalam jurnalnya menjelaskan salah satu pemanfaatan ilmu 
pengetahuan teknologi dalam pelayanan kesehatan masyarakat, yaitu berupa layanan teknologi komunikasi di salah satu klinik kesehatan. Hasil yang didapatkan memberi gambaran bahwa kemajuan ilmu pengetahuan yang di aplikasikan pada teknologi terbaru mempercepat pelayanan kepada pasien klinik tersebut.

\section{SIMPULAN}

Ilmu pengetahuan merupakan bagian penting dari kehidupan manusia. Akal yang diberikan, menghantarkan manusia untuk terus memperbaharui berbagai pengetahuan yang dimilikinya. Hal ini digunakannya untuk bisa bertahan hidup dan menghindarkan dirinya dari bahaya. Ilmu pengetahuan yang luas, menjadikannya tidak pernah lekang oleh waktu. Peningkatan kemampuan seorang manusia menjadikan ilmu pengetahuan pun meningkat.

Pada era revolusi industri 4.0 dengan ikonnya yaitu perkembangan teknologi yang pesat tidak menjadikan ilmu pengetahuan hilang ditelan masa. Ilmu pengetahuan yang berkedudukan sebagai dasar seluruh aspek kehidupan manusia juga berperan besar dalam terjadinya perkembangan era yang sangat pesat ini. Pada era ini, teknologi yang berkembang ikut mempermudah perluasan ilmu pengetahuan. Sehingga, di setiap aspek kehidupan yang berkembang maju ada peran ilmu pengetahuan yang mendasarinya

\section{DAFTAR PUSTAKA}

Jalaluddin. Filsafat Ilmu Pengetahuan. Edisi 1. Jakarta: Rajawali Pers. 2013.

Prasetyo, Hoedi dan Wahyudi Sutopo. Industri 4.0: Telaah Klasifikasi Aspek dan Arah Perkembangan Riset. Jurnal Teknik Industri , 13 (1): 17-26. 2018

Kosim, Muhammad. Ilmu Pengetahuan Dalam Islam (Prespektif FilosofisHistoris). Tadris, 3 (2): 121-140. 2008.

Karim, Abdul. Sejarah Perkembangan Ilmu Pengetahuan. Fikrah, 2 (1): 273-289. 2014. Rusmini. Dasar dan Jenis Ilmu Pengetahuan. Edu-Bio, 5: 79-94. 2014. 
Syamsuar dan Reflianto. Pendidikan dan Tantangan Pembelajaran Berbasis Teknologi Informasi di Era Revolusi Industri 4.0. Jurnal Ilmiah Teknologi Pendidikan, 6(2). 2018.

Sutandra, Lagut dan Sulaiman. Analisis Layanan Teknologi Komunikasi Klinik Fisioterapi Siti Hajar Era Revolusi Industri 4.0. Jurnal Sistem Informasi, 03 (01): 36-45. 2019.

Surajiyo. 2014. Sejarah, Klasifikasi, dan Strategi Perkembangan Ilmu Pengetahuan. Seminar Nasional Pendidikan Sains IV 2014, 1-8.

Prasetyo, Banu dan Umi Trisyanti. 2018. Revolusi Industri 4.0 dan Tantangan Perubahan Sosial. Prosiding SEMATEKSOS 3 "Strategi Pembangunan Nasional Menghadapi Revolusi Industri 4.0”, 22-27.

Sangaji, Niko Dkk. 2019. Pengaruh Revolusi Industri Pada Kewirausahaan Untuk

Kemandirian Ekonomi. Seminar Nasional dan Call Of Paper Seminar Bisnis Magister Manajemen, 226-232.

Surani, Dewi. 2019. Studi Literatur: Peran Teknolog Pendidikan Dalam Pendidikan 4.0. Prosiding Seminar Nasional Pendidikan FKIP, 456-469.

Cholily, Yus Mochamad Dkk. 2019. Pembelajaran di Era Revolusi Industri 4.0. Seminar Nasional Penelitian Pendidikan Matematika (SNP2M) 2019 UMT, $1-6$.

Arti Kata Pengetahuan https://kbbi.kemdikbud.go.id/entri/pengetahuan ( Diakses pada 20 Juni 2020)

Arti Kata Eksistensi https://kbbi.web.id/eksistensi(Diakses Pada 20 Juni 2020) 